\title{
MANAGEMENT OF SOLID RESIDUES IN URBAN CENTERS: DIAGNOSIS OF SOLID RESIDUES IN THE MUNICIPALITY OF IBIRITÉ/MG
}

\section{GESTÃO DE RESÍDUOS SÓLIDOS EM CENTROS URBANOS: DIAGNÓSTICO DO GERENCIAMENTO DE RESÍDUOS SÓLIDOS NO MUNICÍPÍO DE IBIRITÉ/MG}

\author{
Francielen Ferreira Montaldi \\ MBA em Perícia, Auditoria e Gestão Ambiental \\ Gustavo Aveiro Lins \\ gu.lins@terra.com.br \\ CEDERJ/SEE-RJ/CEDAE
Roberto Ricardo Rachid Saab Barbosa Cunha rachidsaab@gmail.com
Observatório Urbano/OUERJ/UN-Habitat \\ Manoel Gonçalves Rodrigues \\ manoel.rodrigues@terra.com.br \\ Observatório Urbano/UERJ/UN-Habitat \\ Josimar Ribeiro de Almeida \\ jralmeida@usp.br \\ Observatório Urbano/UERJ/UN-Habitat
}

\begin{abstract}
Most of the city halls is not self-sufficient to manage the needs of sanitation of the city appropriately. In the attempt of supplying that demand, partnerships are accomplished, some types services, that not always they are accomplished in agreement with the political philosophy of the municipal district. They lack besides a technical managerial body with domain on what will be administered, financial resources for us to be applied. The lack of a solid database, added to the reflex of the behavior of the common sense, it favors mistaken interpretations in the socket of decision. That has been committing the quality of life of the population, of the city and adjacent areas. In the past of the administrative administration, the treatment given to the subject prioritized the services rendered of water and sewer, what was considered basic sanitation, that actually, he/she would still need to be complemented by the service of collection of residues, drainage of pluvial waters and control of vectors. Epidemics of diseases before eradicated or controlled, today they are part of our daily one as to primness and the malaria. The social cost is also expensive, tends in view that many municipal districts have irregular disposition areas, as the to open sky, base of the people's survival marginalized the society. Like this, the accomplishment of that work seeks the rising of data capable to compose a system of information of solid sanitation for the municipal district. Starting from the Program of Modernization of the Setor Saneamento (PMSS), it was thrown in November of 2004, the first Diagnosis of the Handling of Urban Solid Residues, with reference of data of the year of 2002, of the National System of Information on Sanitation (SNIS), main reference for the development of this
\end{abstract}


research. With the popularization of that annual, the National Politics of Environmental Sanitation PNSA - he/she foresees the structuring of an appropriate system of information to the planning activities, installment and regulation, as well as the participation and social control of the services. It is the first time that the component solid residue is considered in the database of SNIS. The importance of the system in the federal sphere doesn't substitute the need of systems of information in the state and municipal levels (with the width demanded at each level), according to the legal responsibilities about the installment and regulation of the services. In the same way that is important the integration of the bases of data. It is important to emphasize that the material used for the study, he/she doesn't have the purpose of detaching tendencies, merits and eventual demerits. The fundamental purpose is to present the vision of the situation of the services of handling of Solid Residues of Brazil, that is going to the encounter of the main purpose of this research that presents the situation of the administration of the services of public cleaning of the municipal district of

Keywords: Solid residues, epidemics, collection of residues.

\section{RESUMO}

A maioria das prefeituras não é auto-suficiente para gerir adequadamente as necessidades de saneamento da cidade. Na tentativa de suprir essa demanda, são realizadas parcerias, terceirizando alguns tipos serviços, que nem sempre são cumpridos de acordo com a filosofia política do município. Faltam além de um corpo gerencial técnico com domínio sobre o que vai ser administrado, recursos financeiros para serem aplicados. A falta de um banco de dados consistente, somado ao reflexo do comportamento do senso comum, favorece interpretações equivocadas na tomada de decisão. Isso tem comprometido a qualidade de vida da população, da cidade e regiões circunvizinhas. No passado da gestão administrativa, o tratamento dado ao assunto priorizava a prestação de serviços de água e esgoto, o que era considerado saneamento básico, que na verdade, precisaria ainda ser complementado pelo serviço de coleta de resíduos, drenagem de águas pluviais e controle de vetores. Epidemias de doenças antes erradicadas ou controladas, hoje fazem parte do nosso cotidiano como a dengue e a malária. $O$ custo social também é caro, tendo em vista que muitos municípios têm áreas de disposição irregulares, como os vazadouros a céu aberto, base de sobrevivência das pessoas marginalizadas à sociedade. Assim, a realização desse trabalho visa o levantamento de dados capaz de compor um sistema de informação de saneamento consistente para o município. A partir do Programa de Modernização do Setor Saneamento (PMSS), foi lançado em novembro de 2004, o primeiro Diagnóstico do Manejo de Resíduos Sólidos Urbanos, com referência de dados do ano de 2002, do Sistema Nacional de Informação sobre Saneamento (SNIS), principal referência para o desenvolvimento desta pesquisa. Com a divulgação desse anuário, a Política Nacional de Saneamento Ambiental - PNSA - prevê a estruturação de um sistema de informação adequado às atividades de planejamento, prestação e regulação, bem como a participação e controle social dos serviços. É a primeira vez que o componente resíduo sólido é considerado no banco de dados do SNIS. A importância do sistema na esfera federal não substitui a necessidade de sistemas de informações nos níveis estadual e municipal (com a amplitude exigida a cada nível), segundo as responsabilidades legais sobre a prestação e regulação dos serviços. $\mathrm{Da}$ mesma forma que é importante a integração das bases de dados. É importante ressaltar que o material utilizado para o estudo, não tem o propósito de destacar tendências, méritos e eventuais deméritos. O propósito fundamental é apresentar a visão da situação dos serviços de manejo de Resíduos Sólidos do Brasil, que vai ao encontro da principal finalidade desta pesquisa que apresenta a situação do gerenciamento dos serviços de limpeza pública do município de lbirité.

Palavras-chave: Resíduos Sólidos, epidemias, coleta de resíduos.

\section{INTRODUCTION}

The management of solid residues in cities is considered one of the main challenges nowadays. This complex issue involves social, financial and environmental aspects to be worked together, what requires knowledge of the 
reality of each municipality.

But is the lack of perception of that environment that has compromised the efficiency of management. It is known that despite the striving that Prefectures have been made, yet there are not parameters for urban solid residues planning and control (MCIDADES, 2004; IBAM, 20012; LIMA, 2001).

The disordered growth of cities (a reflection of increase in population) and the excessive consumption are factors that promote the growth of the volume of waste produced, which in most cases have no place suitable for final disposal.

According to Brazilian Institute of Municipal Administration (IBAM, 2001), the income by the municipalities are sufficient to cover operation costs, treatment and environmentally correct discharge of solid waste.

According to the Ministry of Cities (2004), the lack of references is observed mainly through the lack of data relevant for urban solid waste management, whose survey is necessary for structuring a complementary system of sanitation, important at municipal, state and federal level.

Once structured, these data sharing enables minimization of the problem for some municipalities and the settling of the issue for others, promoting better life quality for society as a whole and to the physical space that it occupies and boasts.

It is important to highlight that this is the only moment the word "garbage" will be written in this work to show that this term is no longer adequate to deal with the problems it brings. The word has a meaning which is unworkable, unusable, which is extremely subjective.

As daily behavior requires changes and creating new habits, there is the need for a new proper treatment for the matter. What society discharges in fact are materials of potential reuse (for after being recycled), tailings (materials not able to be reused) and organic material.

Thus, before discussing what to do with the residues, it is needed to identify the real need of consumption, prioritizing the reduction, generating only the inevitable one, exterminating the excesses, what causes the creation of a complex and expensive environmental passive.

The environment has suffered several anthropic aggressions. Amongst them, 
the generation and final dispose of residues represent one of the main challenges of urban centers that grow without control, compromising capacity of management for residues derived from disordered urbanization.

Albeit justifiable by public health benefits achieved, costs for maintaining sanitation of a city are high. Financial resources, installations, equipment and labor force required for this context are currently insufficient to plentifully meet the sanitation needs.

Municipalities are the direct responsible for city cleanliness. Therefore, it is their competence the whole management of treatment and adequate dispose for solid residues produced.

However, practices of solid residues management developed in Brazil, do not meet simultaneously region needs and legal conditions, revealing inefficacy, without assuring the proper protection to environment and society, wasting precious financial resources.

The fact of the own municipality (small, medium and big sized) does not have a structured system of sanitation data makes even more difficult the realization of an efficient management of urban solid residues. It knows that it must sanitize, but sometimes it does not exactly knows for how many, where, with whom, how, how much does it cost, if there are sufficient equipment for the works, amongst other relevant factors. On this context, what is the current situation of the management of urban solid residues of the municipality of Ibirité, in Minas Gerais?

The objective of this work is to undertake the diagnosis of the management of the urban solid residues of the municipality of Ibirité, in Minas Gerais.

\section{RESEARCH EXPOSURE}

The presented data of the municipality were obtained from a documentary research of the Relatório de Controle Ambiental - RCA - (MONTEIRO e COSTA, 2004), of the issue Panorama dos Resíduos Sólidos Urbanos carried through by the Associação Brasileira de Empresas de Limpeza Urbana (ABRELPE, 2005) of the SNIS tables filled up or partially filled up (MCIDADES, 2004), of the surveys not directed with the SEMAS administration staff, beyond the understanding obtained 
gotten from the systematic observation of the administrative routine from Department of Public Cleanness.

In this municipality, in particular, public cleaning services are regularly collected on inhabitants' water bill. But for the vacant lands, the collection I made through the payment of Municipal Real Estate Tax IPTU.

\section{Quantitative characteristics}

The most recent records of waste production in the city had already been measure according to a report of environmental control held in 2004. Table 1 presents data concerning per capita production of residues in the municipality:

Table 1 - Produção per capita de Resíduos Sólidos em Ibirité.

\begin{tabular}{ll}
\hline DISCRIMINATION & g/hab.dia \\
\hline Commercial/domestic & 500 \\
Septic (RSS) & 5 \\
Garden/Pruning & 22 \\
Civil Construction & 400 \\
Sweeping & 40 \\
\hline
\end{tabular}

Fonte: COSTA; MONTEIRO, 2004.

Thus, the data in table shows that each inhabitant of the municipality raises $0,967 \mathrm{~kg}$ of municipal waste per day, production which is within the average range of Latin America that is $0,9 \mathrm{~kg} /$ inhabitant per day.

\section{Qualitative characteristics}

During the documentary research, the gravimetric characterization was identified, taking into account the provisions and guidelines of the NBR -10.007 ABNT - "Waste Sampling - Procedures", according to data presented in table 2.

Tabela 2 - Composição gravimétrica dos resíduos sólidos de lbirité. 


\begin{tabular}{lll}
\hline ORDER & COMPONENT & $\%$ \\
\hline 1 & Paper & 3,85 \\
2 & Cardboard & 2,52 \\
3 & Hard plastic & 2,59 \\
4 & Plastic wrap & 5,29 \\
5 & PET & 2,22 \\
6 & Glass & 0,99 \\
7 & Aluminum & 0,00 \\
8 & Metals & 2,83 \\
9 & Organic matter & 72,68 \\
10 & Other tailings & 7,03 \\
\hline TOTAL & & 100 \\
\hline
\end{tabular}

Fonte: COSTA; MONTEIRO, 2004.

Analyzing the previous table, it is verified that more than $70 \%$ of the waste is organic material, which shows great potential for the practice of composting, one of the most suitable forms for organic waste. However, for the implantation of that treatment, it is essential the study of economic and financial feasibility for verifying real possibilities that the municipality has to run the service.

Only $20,29 \%$ of the inert waste have potential for recycling, small percentage that does not have a large infrastructure for segregation and administration of these materials, but also does not relieve the systematized organization of cooperatives. In addition to establishing partnerships with the pickers of RECYCLABLE MATERIALS (and not tailings and organic residues!), it is desirable that they also be assisted by social programs.

\section{Major urban cleaning services}

Considering the presented PC presented, it can be noticed that in most of them, some services were coincident (sweeping, weeding and gathering that includes the issue of transportation), albeit with diversified nomenclature (scraping, mowing).

Thus, was set the following structure of public cleaning, highlighting the activities that require greater attention to management, shown in figure 1 below: Once identified, then, the treatment given to these activities by the Administration responsible for the urban cleaning of the municipality of Ibirité was analyzed. 
Figure 1 - LP system services that demand greater attention to management.

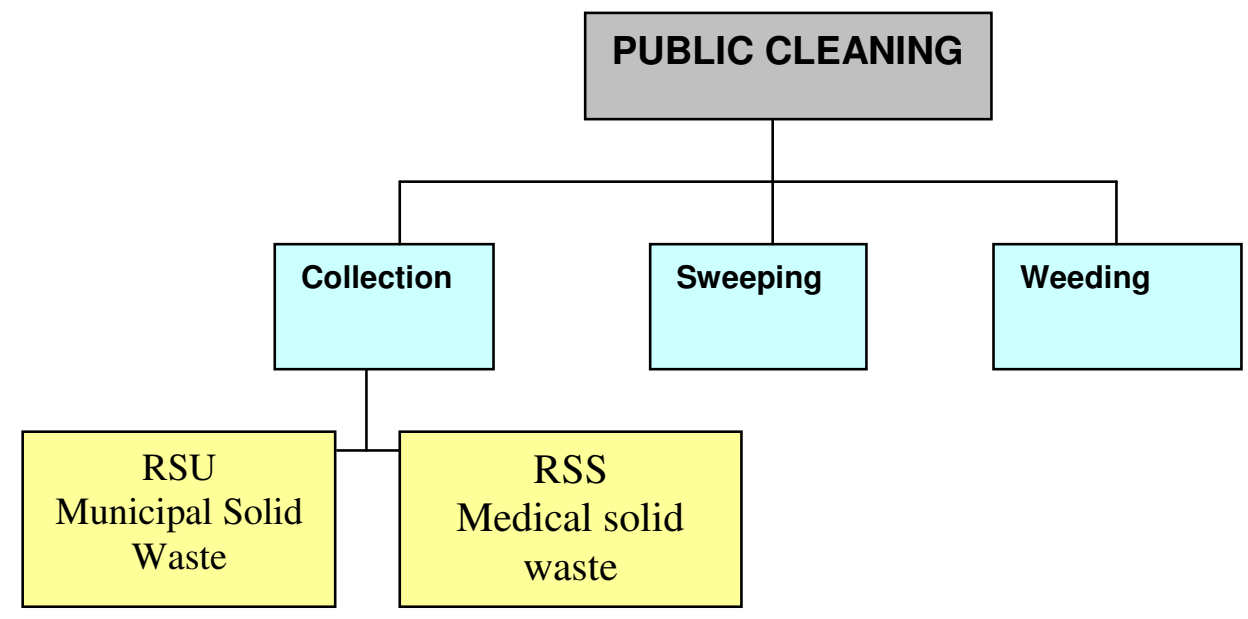

\section{Sweeping}

During the studies, the following information about the sweeping service was raised:

- $\quad$ there is no mechanized sweeping;

- there is no outsourced service. The responsible ones to execute that activity are 42 sweepers and 2 in charges of SEMAS;

- $\quad$ the average of the extension of gutter swept per day is of approximately 12,5 km, from Monday to Saturday; and,

- the production is estimated by the number of bags used by day, with the information of their volume.

The last descriptive guideline of this service is from 1998. Since then, it has gone through changes according to the emergence of new demands for service.

There are 8 routes defined being:

- 3 in the central area;

- 1 in Duval de Barros neighborhood;

- 1 in Palmares neighborhood;

- 1 in Washington Pires neighborhood;

- 1 in Sol Nascente neighborhood and; 
- 1 in Canal and Jardim das Rosas neighborhood.

Regarding the service frequency, the main region is swept everyday (mainly the commercial area) by 4 teams, being each one composed by 2 sweepers and 1 street cleaner with a cart to pick the residues. The region of Duval de Barros is also swept everyday by 4 teams, on alternate streets. And the region of Canal is swept at least 2 times per week.

In all, sweeping teams utilize nine carts called "lutocar". Each one fills in average 7 bags with capacity of 100 liters per day. Thus, about 6.300 liters of waste are removed from the sweeping avenues daily.

When considering that $12,5 \mathrm{~km}$ of gutters are swept every day, generating 6.300 liters of waste, there is a specific production of $504 \mathrm{l} / \mathrm{km}$ a day. This value is below the average of the production of FUNASA (2004) which is from 850 to 1.260 $1 / \mathrm{km}$ a day. The average of sweeper per each 1.000 inhabitants also was below the reference parameter that is from 0,40 to 0,80 . Ibirite value reached the result of 0,25 .

Amongst the possible interpretations, it can be said that the low rates occur due to the high level of population's education, or the few generation of residues from activities of maintenance of the own ecosystem, for example, the few trees along public roads.

\section{COLLECTION and TRANSPORT}

The information on operational structure, frequency and costs for services of solid waste collection, through non-directed interviews, it was observed that there is night collection in the municipality.

Frequency in urban center is of 6 times per week. In other parts of the city, 3 times per week on alternate days.

But the information on collection of domiciliary, public and civil construction solid residues permitted the identification of the following information:

- $\quad 133.948$ inhabitants ( $80 \%$ of the population) are served by regular household collection; 
- SEMAS is the main executor agent of collection, including construction waste, and rarely, outsources some source of service;

- the public residues are collected along with the household;

- there is no public waste or household shipment between municipalities;

- it is planned, but the selective collection is not yet taken;

- the use of scales is not done; and

- The average distance from the urban center to the management unit is approximately $8 \mathrm{~km}$.

Regarding drivers and collectors 1 , SEMAS offers 54 professionals, being 52 from Prefecture (48 street cleaners and 2 drivers) and 2 drivers with individual contracts. The urban cleaning system has available a fleet of 01 bodywork truck, 05 compacter trucks; 06 wagons, 01 truck Brooke and 20 buckets for rubble.

\section{Weeding and Mowing}

Through interview not directed, information about services of weeding and mowing were collected, which allowed to the knowledge that:

- the service of weeding and mowing is done manually and mechanically;

- $\quad$ chemical products are not used and;

- the number of workers involved is 42 sweepers and 50 street cleaners for the service of weeding.

\section{Solid waste from health services (RSS)}

Regarding RSS management in the municipality, it was pointed out that the implementation of the collection is exclusively from SEMAS. In the municipality, there are 95 health establishments. They are 67 establishments like clinics, laboratories and similar others and 28 hospitals and medical service stations.

In the last survey conducted by SEMES in 2005, it was measured the production of $1.100 \mathrm{~kg} /$ week, from Monday to Friday (4.400 kg/month). Respecting this frequency, the daily production is of $220 \mathrm{~kg} /$ day. But concerning the way the data were disposed, it is not possible to compare them with the average of productivity of Latin America from FUNASA (2004) that is of $3 \mathrm{~kg} / \mathrm{bed} / \mathrm{day}$, or the average of national productivity that is of $2,63 \mathrm{~kg} / \mathrm{bed} /$ day. 


\section{Other Services}

In the municipality, washing services of roads and squares; cleaning of vacant lands (which is the owner's responsibility) and collection of batteries are not taken.

- Thus, the following activities are practiced:

- $\quad$ pruning of trees and lawns;

- cleaning of fairs and markets;

- cleaning of culvert;

- $\quad$ curb painting;

- removal of dead animals;

- collection of old tires; and,

- $\quad$ collection of bulky residues.

Thus, following, the structure of public cleaning of lbirité is presented.

Figura 2 - Estrutura do Sistema de Limpeza Pública de Ibirité.

\section{PUBLIC} CLEANING 


\section{LANDFILL}

\section{Location}

The municipality of Ibirité counts with a controlled landfill installed in one area located within the area bounded by the APA-South, Casa Branca Upland, at the place named Capão Redondo.

This controlled landfill was the target of a campaign for improvements by the previous and the current municipal administration, in partnership with the State Foundation for the Environment (FEAM).

However, though it has been achieved the significant improvement of conditions for landing, it was verified seriousness of the environmental drawback of having a unit of final disposal for urban solid residues RSU in an area of environmental protection. Even, there are several springs which are used as sources for the public water supply in the municipality. Besides, the controlled landfill does not have many legal devices previewed in the current environmental legislation that is the Normative Deliberation 052/2001 from COPAM. 
During the supervised internship, the place was not visited due to the nonavailability of the secretariat's staff's schedule for the follow-up of the visit and nonavailability of vehicles.

\section{Characterization}

The analysis of data obtained from the processing units permitted the raise of the following information:

- $\quad$ The activity started in 1995 and;

- The controlled landfill is operated by the Superintendence for Urban Cleaning through SEMAS.

The municipalities of Mário Campos and Sarzedo send urban residues to the controlled landfill of Ibirité.

The unit does not have operation license, administrative installation, basis proofing, night surveillance and houses. However, there are daily shelter for disposed materials and gases (not burnt) drainages for rainy waters. The slurry is also drained, but nor recirculated and amenable for treatment.

\section{Quantity received}

The landfill receives 91 tons of residues a day, by collections taken from Monday to Saturday, according to table 3.

Table 3 - Quantity of waste received at the landfill controlled of lbirité.

\begin{tabular}{lll}
\hline MUNICIPALITY & QUANTITY & PERCENTAGE \\
& (TONNES) & (\%) \\
\hline Ibirité & 72,2 & 80,99 \\
Mário Campos & 5,6 & 6,16 \\
Sarzedo & 11,7 & 12,85 \\
\hline TOTAL & 91,0 & 100 \\
\hline
\end{tabular}

Fonte: SEMAS, 2009.

Table 4 - Estimated production per period. 


\begin{tabular}{ll}
\hline Weekly & 546 \\
Monthly & 2.184 \\
Annual & 26.208 \\
\hline
\end{tabular}

Fonte: SEMAS, 2009.

Based on the data of table 3, it was made as shown in table 4: Considering still the total of residues monthly produced in Ibirité $(72.200 \mathrm{~kg})$, it can be found the total of the production of public and household residues, once yet also mentioned the monthly total of health solid residues, produced by the municipality $(4.400 \mathrm{~kg})$, table 5:

Table 5 - Monthly production by type of residue.

\begin{tabular}{ll}
\hline WASTE & Month Kgm \\
\hline Home care and Public & 67.800 \\
Health & 4.400 \\
\hline TOTAL & 72.200 \\
\hline Fonte: SEMAS, 2009.
\end{tabular}

\section{METHODOLOGY}

The current research was mainly developed by the case study method. According to YIN (1981), this method is a strategy of investigation which seeks to examine a contemporaneous phenomenon within its context, where the quantitative or qualitative evidence can be worked (ROESCH, 1999).

In the case study, the researcher performs most of the work in person, because the importance of his own direct experience with the study situation is emphasized (GIL, 2002).

The research is fundamentally based on the first diagnosis of the urban solid residues management - 2002, first work which raised data at national level made by samples in the country, undertaken by the Ministry of Cities, through the Program for the Sanitation Modernization Sector (MCIDADES, 2004).

The survey method was also used. It has the main objective of obtaining information on the urban solid residues management for action or prediction, without saying the causes, though allows the match of some results $(\mathrm{ROESCH}$, 
1999).

It is still characterized by the direct interrogation of people who work in a determined work environment, whose conditions are wished to be known, aiming to reveal data which permit the planning and better control relating to the sanitation administration in the municipality (GIL, 2002).

Some tables of the mentioned issue were used, being adapted to the municipality features and answered by the researcher next to the staff responsible for the public cleaning. However, the exposition of the raised data many times will occur through text form instead of table itself, since only part of the information obtained gave a satisfactory response to what was requested.

In this was, it is characterized the field research of quantitative-descriptive character and, simultaneously exploratory.

Quantitative-descriptive because it consists on investigation of empirical research, whose main objective is to outline or analyze the characteristics of facts or phenomena, providing data for verifying hypothesis. Exploratory-descriptive in combination because it increases the researcher's familiarity with the environment, bringing clearness of concepts besides completely describe determined phenomenon.

Both quantitative and/or descriptive descriptions as also as accumulation of detailed information like the obtained through the participating observation can be found where the representative systematic character is the precedence (MARCONI E LAKATOS, 2002).

Through systematic and participating observation it is possible to have direct and satisfactory means to study phenomena, with low evidence of introspection or reflection and perception of data shown assurance non-constant in the guidelines for interviews or questionnaires (MARCONI E LAKATOS, 2002).

Data collection was also carried through by documentary research which normally complements interviews (ROESCH, 2002).

The documentary research used materials that did not received any analytical treatment or even new elaboration in accordance with the research objectives. On one hand, there are the primary documents that did not receive any 
analytical treatment like the documents conserved in archives. On the other side, second had documents, that have been already analyzed in some way, such as research reports, enterprises reports, statistical tables, etc. (GIL, 2002).

Through the opportunity to have a direct contact with the workers of the administration of the municipal urban cleaning management, non-directed interviews were applied in order to better know their own work routine. This procedure is used to socially investigate the data collected, or to help in the diagnosis or treatment of a social problem such as the urban residues (MARCONI E LAKATOS, 2022).

The data obtained for the realization of this study on urban residues management of the municipality of Ibirité presenting its reality were quantitative and qualitatively analyzed.

\section{CONCLUSION}

The current study revealed administrative failures which fatally compromise the efficiency of the management of services which compound the Public Cleaning system.

The most impacting failure regards the lack of mechanisms for controlling data inherent to the urban solid residues management. These, when exist, are not easily identified, due to the inconsistence of their own presentation.

The regular elaboration of a plan for activities execution generates essential information for the success in service execution.

The stiffness of the structure of management of Public Bodies, the small number of trained professionals responsible for the urban solid residues management and the excess of bureaucracy mean rigid managerial obstacles which challenge even more the success of an efficacy administration.

Having seen it, without having other means of feasible administrative techniques, the urban solid residues units' managers spend exceptional efforts and professionalism to keep the urban cleaning system running with an old dated and unstructured database, allied to financial resources limitation.

Inevitably, the responsible for decision-making act as according to the urgent 
priorities of problems and matters related to the Public Cleaning system, which are raised along the shift period. This behavior favors the practice of immediate actions that inhibits the possibility to treating the raised data, compromising the sustainability of the obtained data that normally possesses a temporary effect.

Whereas, the administrative staff has managed to satisfy, even partially, the demands of work referred to the urban solid residues management. But it is needed to solve the risk of collapse of the urban cleaning system through plans and instruments of management which enables the raise, structure and, mainly, data control to verify the work quality performed by the competent unit and, consequently, significant results on the municipal urban solid resources management.

\section{REFERÊNCES}

ASSOCIAÇÃO BRASILEIRA DE EMPRESAS DE LIMPEZA PÚBLICA E RESÍDUOS ESPECIAIS. Panorama dos resíduos sólidos no Brasil. São Paulo: ABRELPE, 2005.

FUNDAÇÃO NACIONAL DE SAÚDE. (Manual de Saneamento. Capítulo 4. p. 227286. 3. ed. Ver. - Brasília: Fundação Nacional de Saúde, 2004.

GIL, A.C. Como elaborar projetos de pesquisa. 4. ed.- São Paulo: Atlas, 2002.

LIMA, J.D. Gestão de Resíduos Sólidos Urbanos no Brasil. João Pessoa: EMLUR, 2001.

MANUAL DE GERENCIAMENTO INTEGRADO DE RESÍDUOS SÓLIDOS/ José Henrique Penido Monteiro [et al.]; coordenação técnica Victor Zukar Zveibil. Rio de Janeiro: IBAM, 2001.

MARCONI, M. A; Lakatos, E .M. Técnicas de pesquisas, elaboração, análise e interpretação de dados.- 5. ed. São Paulo: Atlas, 2002.

MONTEIRO, M. B; Costa, M. B. Relatório de Controle Ambiental do Aterro Sanitário. Ibirité, 2004.

PROGRAMA DE MODERNIZAÇÃO DO SETOR SANEAMENTO. Sistema Nacional de Informações sobre Saneamento: diagnóstico da gestão de 
manejo de Resíduos Sólidos urbanos - 2002. Brasília: MCIDADES.SNSA: IPEA, 2004.

ROESCH, S. M. A. Projetos de estágio e de pesquisa em Administração: guia para estágios, trabalhos de conclusão, dissertações e estudos de caso; colaboração Grace Vieira Becker, Maria Ivone de Mello.- 2. ed. - São Paulo: Atlas, 1999.

Recebido: 15/11/2013

Aprovado: 27/11/2013 